\title{
Non-Whipple Operations in the Management of Benign, Premalignant and Early Cancerous Duodenal Lesions
}

\author{
ALEXANDROS PAPALAMPROS ${ }^{1 *}$, DEMETRIOS MORIS ${ }^{1,2^{*}}$, ATHANASIOS PETROU $^{3}$, \\ NIKOLAOS DIMITROKALLIS ${ }^{1}$, IOANNIS KARAVOKYROS ${ }^{1}$, DIMITRIOS SCHIZAS ${ }^{1}$, \\ IOANNA DELLADETSIMA ${ }^{4}$, THEODORE N. PAPPAS ${ }^{5}$ and EVANGELOS FELEKOURAS ${ }^{1}$ \\ ${ }^{1}$ First Department of Surgery, Laikon General Hospital, Medical School, \\ National and Kapodistrian University of Athens, Athens, Greece; \\ ${ }^{2}$ Department of Surgery, The Ohio State University Comprehensive Cancer Center, \\ The Ohio State University, Columbus, OH, U.S.A.; \\ ${ }^{3}$ Nicosia Surgical Department, Division of Hepatobiliary Pancreatic Surgery, \\ Nicosia General Hospital, Nicosia, Cyprus; \\ ${ }^{4}$ Department of Pathology, Medical School, National and Kapodistrian University of Athens, Athens, Greece; \\ ${ }^{5}$ Department of Surgery, Duke University, Durham, NC, U.S.A.
}

\begin{abstract}
Aim: We reviewed our 20-year experience with non-Whipple operations (pancreas-preserving duodenectomy and transduodenal ampullectomy) for the treatment of benign, premalignant or early-stage malignant duodenal lesions. Patients and Methods: Twenty-four patients who underwent non-Whipple operations between January 1996 and December 2015 were identified from an institutional database and retrospectively analyzed. Results: Between 1996 and 2015, 10 patients underwent pancreas-preserving duodenectomy and 14 patients underwent transduodenal ampullectomy. The mean follow-up was 25.8 months (range=6-54 months) and no patient was lost to follow-up. Eighteen patients had preoperative diagnosis of duodenal adenomatosis, three patients had preoperative diagnosis of duodenal adenocarcinoma, one had a bleeding polyp and two had localized inflammation. Average operative time was $145 \mathrm{~min}$ (range $=127-168 \mathrm{~min}$ ) for transduodenal ampullectomy and $183 \mathrm{~min}$ (range $=173-200 \mathrm{~min}$ ) for pancreas-preserving duodenectomy $(p<0.05)$. The estimated blood loss for transduodenal ampullectomy was $85 \mathrm{vs.}$ $125 \mathrm{ml}$ for pancreas-preserving duodenectomy $(p<0.05)$.
\end{abstract}

*These Authors contributed equally to this study.

Correspondence to: Demetrios Moris, MD, Ph.D., Department of Surgery, The Ohio State University Comprehensive Cancer Center, The Ohio State University, Columbus, OH 43210, U.S.A. Tel: +1 2164442574, Fax: +1 2164454658, email: dimmoris@yahoo.com

Key Words: Pancreas-preserving duodenectomy, surgical ampullectomy, ampullary lesions, pancreatoduodenectomy.
Early postoperative complications were noted in 13 cases (54.17\%). There were no postoperative (90-day) deaths observed in this series and there were no recurrences during follow-up for the patients operated on with neoplastic lesions. Conclusion: For carefully selected patients, transduodenal ampullectomy and pancreas-preserving duodenectomy may be used in place of the Whipple operation for benign and occasionally early-stage malignant (Tis and T1) duodenal and ampullary disease.

Duodenal tumors are rare $(1,2)$ and surgical resection of the duodenum is challenging due to its proximity to and common blood supply with the pancreas (3-5). Some lesions in the duodenum or at the ampulla may be resected endoscopically but this approach is limited to small (less than $2 \mathrm{~cm}$ ) superficial lesions (6). For these reasons pancreaticoduodenectomy (PD) is the most commonly used operation for both benign and malignant duodenal lesions (7). Unfortunately, PD is often associated with postoperative complications, since postoperative pancreatic fistula (POPF) is commonly encountered in these patients due to their soft pancreatic parenchyma and small pancreatic duct (8). In addition, pancreatic head resections are often associated with significant attenuation in pancreatic endocrine and exocrine function (9). Transduodenal ampullectomy and pancreaspreserving duodenectomy are operations that have been used for resecting duodenal lesions and have been reported to have a lower morbidity and mortality than PD (10).

Transduodenal ampullectomy (TDA) is a relatively old operation mainly offered to a very narrow group of patients with ampullary adenoma who have lesions that are large enough to exclude them from having endoscopic resections 
but not so large to warrant PD (10). Emerging data indicate its potential role in resection of early ampullary tumors (11, 12) since it is a less invasive and simple technique, that could potentially provide equivalent clinical outcomes to PD for early ampullary malignancies. The success of TDA is mainly based on the absence of nodal metastasis and the achievement of R0 resection $(13,14)$.

In 1995 Chung et al. (15) published the first series of pancreas-preserving duodenectomies (PPDs) for premalignant duodenal lesions (15). To date, about 270 cases of PPD (partial and total) have been described, with low mortality and variable morbidity rates (15-56). Unfortunately, no large series of PPDs have been published (largest series fewer than 30 cases), but data available suggest that this technique is feasible, safe and may be associated with shorter operative time and reduced blood loss compared to PD (15-56). In addition, PPD enables postoperative endoscopic follow-up of the whole gastrointestinal tract, including the neo-duodenum, for patients with familial adenomatous polyposis (FAP), which account of the majority of patients currently treated with PPD (15-56).

We present a series of non-PD operations (PPD and TDA) for the treatment of benign, premalignant, and early malignant duodenal lesions. The technical aspects, and outcome of these operations are reviewed. We also review the literature concerning the outcome after non-Whipple resections of the duodenum.

\section{Materials and Methods}

Twenty-four patients who underwent PPD and TDA between January 1996 and December 2015 at Laikon General Hospital, Greece and Nicosia General Hospital, Cyprus, were identified from their institutional computer-based databases and retrospectively analyzed. Two senior surgeons performed all operations. Standard demographic and clinicopathological data were collected, including gender, age, presenting symptoms, preoperative diagnosis/indication for PPD/TDA, type of operation, postoperative histological diagnosis, postoperative mortality and morbidity, and follow-up. Intraoperative data included operative time. Operative notes provided information on treatment-related variables, such as indication for resection and specific type of resection. ClavienDindo classification system (57) was used to record the perioperative complications with a major complication classified as grade 3 or more. For patients with two or more complications, the most severe was taken into account. The length of hospital stay for each patient was recorded.

Definition of POPF and other short term outcomes. POPF was defined as drain output on or after postoperative day 3 with amylase content at least three times that of the serum amylase level (58). Fluid collection was defined as that identified through computerized tomographic scan or ultrasound greater than $5 \mathrm{~cm}$ in diameter, with or without clinical relevance. Acute pancreatitis was defined as a threefold increase of normal serum amylase or lipase values after the third postoperative day, confirmed by computed tomographic

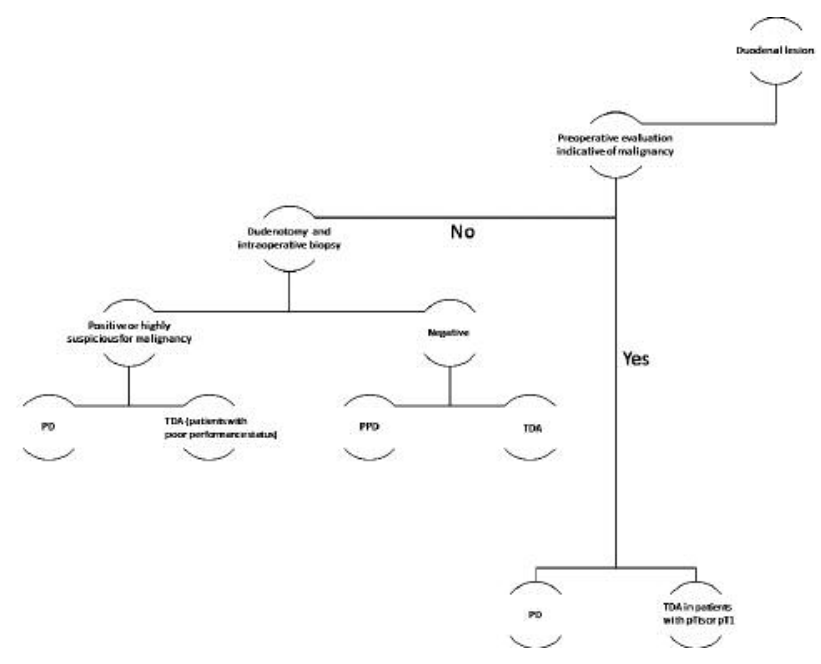

Figure 1. Algorithm of decision-making on duodenal lesions. TDA: Transduodenal ampullectomy, PD: partial duodenectomy, PPD: pancreas-preserving duodenectomy, Tis: tumor in situ.

scan findings and clinical course. Early postoperative hemorrhage and delayed gastric emptying (DGE) were defined according to the International Study Group of Pancreatic Surgery (58-60).

Pre-and postoperative management of patients undergoing PPD and TDA. All patients with benign or early-stage duodenal cancer who were being considered for PPD and TDA were routinely investigated preoperatively with endoscopic ultrasound and biopsies (61) and magnetic resonance cholangiopancreaticography (47). Any case of provisionally benign disease that could not be treated by endoscopic means (median of two endoscopic attempts) was deemed appropriate for PPD or TDA. In most cases where there was an intraoperative suspicion of an invasive disease after frozen section, a PD was performed. Exceptions to this included three cases in which patients had poor performance status and could not undergo PD. They were offered TDA. In addition, patients with poor performance status with $\mathrm{pT} 1$ or pTis disease were offered TDA instead of PD. Figure 1 illustrates our decision-making algorithm for patients with duodenal lesions.

Postoperatively, standardized management included clinical evaluation twice daily and daily analyses of blood and drain-fluid samples as described earlier (62-66). Postoperative mortality was defined as death occurring within 90 days after surgery or during hospital stay.

Operative techniques. TDA: After an extended right subcostal incision, the peritoneal cavity is carefully explored to exclude systematic spread. The second portion of the duodenum is palpated in a bimanual fashion to identify the lesion and the ampulla of Vater. Two-stay sutures (Vicryl 3-0) are placed and a 3-4 cm longitudinal incision is made along to the lateral wall of the second portion of the duodenum opposite the ampullary tumor. In order to achieve better retraction of the lesion, a figure-of-eight suture [polydioxanone (PDS) 4-0] is placed through the mass. A submucosal injection of dilute epinephrine $(1: 10,000)$ beneath the mass is performed to prevent bleeding during the resection and to increase the distance 

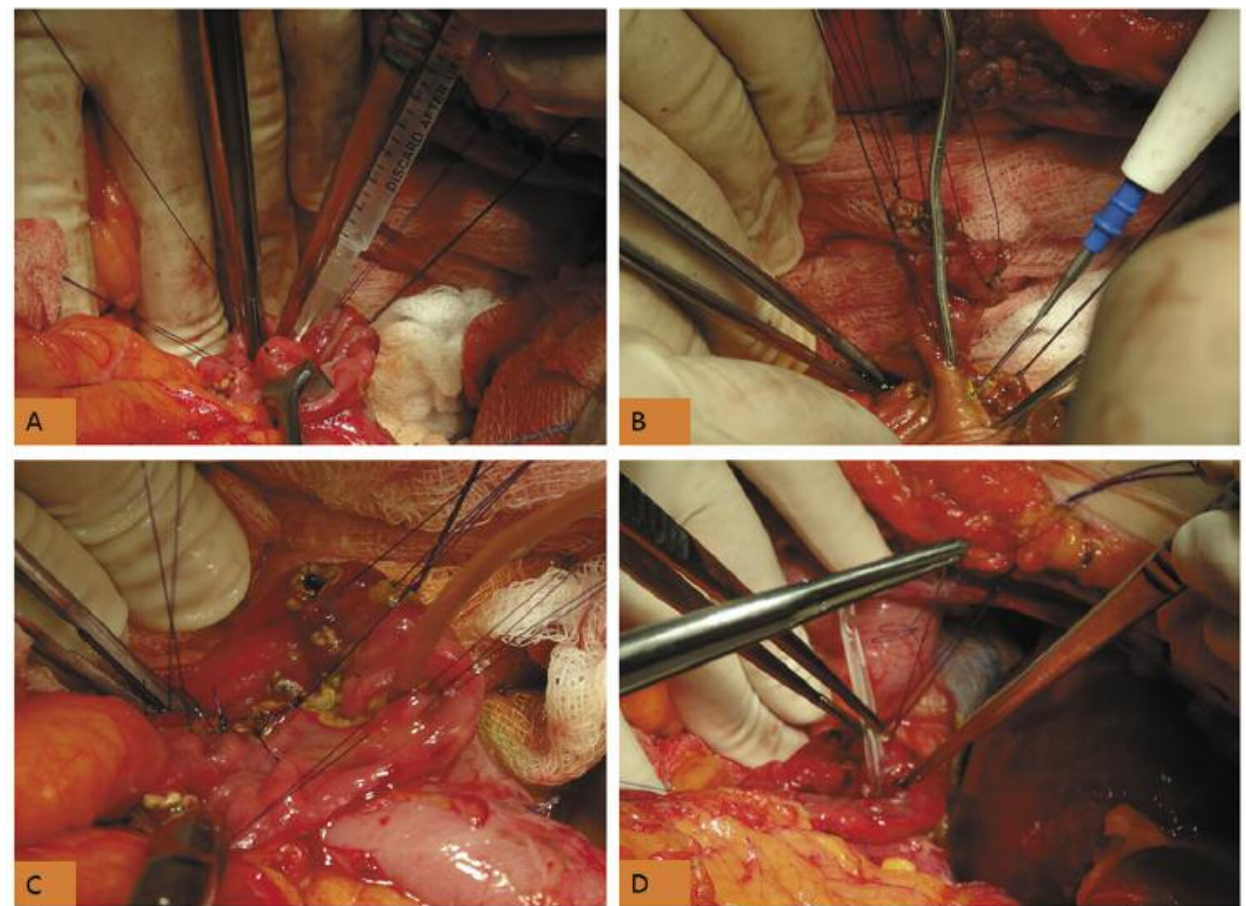

Figure 2. Pancreas-preserving duodenectomy. A: Submucosal injection of dilute epinephrine. Two figure-of-eight PDS 4-0 stitches are placed for better retraction of the tumor. B: Excision of the lesion with the electrocautery. The ampulla is identified. C: The defect of the posterior wall of the duodenum is sutured and a nelaton catheter is inserted in the ampulla. D: The edge of a nelaton catheter is inserted in the ampulla (internal stent) after the completion of the sphinctiroplasty.
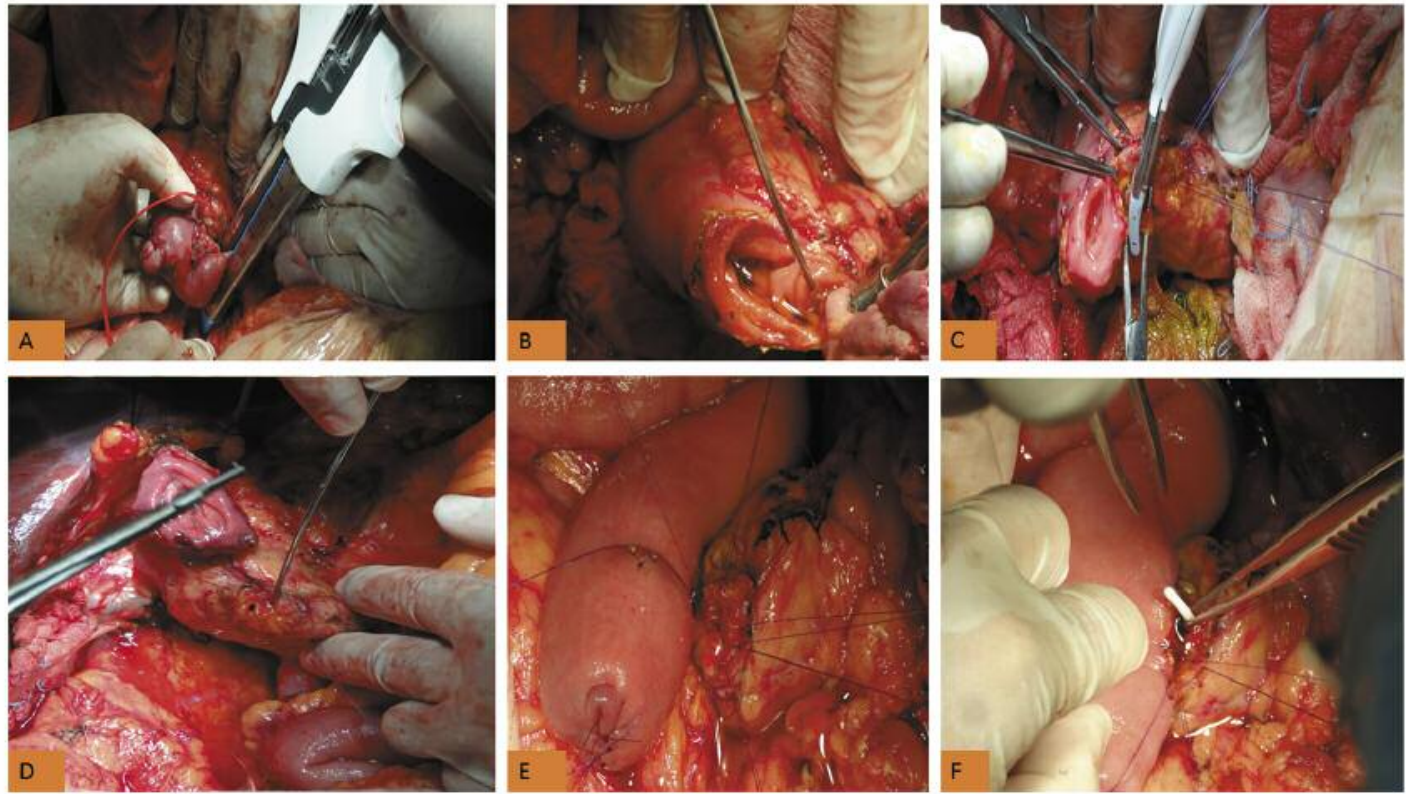

Figure 3. Transduodenal ampullectomy. A: Division of the 4th portion of the duodenum and identification of the tumor. B: Identification of the ampulla. C: Preparation of the first and second portion of the duodenum from the pancreatic head with Ligasure (Covidien, Colorado, USA). D: Identification of the common bile duct and the main pancreatic duct. Stay sutures (PDS 5-0) are placed. E: A duct-to-mucosa anastomosis is performed. F: Insertion of a pig-tail catheter as an internal stent in the main pancreatic duct. 
between the base of the lesion and the serosa of the posterior wall of the duodenum (Figure 2A). The dissection begins at the 11 o'clock position using the diathermy heading towards the common bile duct (CBD) (Figure 2B). When the lumen of the CBD is identified, serial 5-0 PDS sutures are placed to approximate the bile duct to the duodenal mucosa. The pancreatic duct is usually identified at the 1 or $2 \mathrm{o}$ ' clock position and is then approximated to the duodenal wall in the same fashion as the CBD. When the ampullary mass is completely resected, both ducts are reapproximated with two to three interrupted 5-0 PDS sutures and the specimen is sent for frozen section histopathological examination. A 6-Fr pig-tail catheter is inserted in each duct separately to maintain its patency and fixed with a 6-0 PDS suture. The mucosa of the posterior wall of the duodenum is approximated by single 4-0 PDS sutures (Figure 2C). Finally, a double-layer transverse duodenal closure is performed using 4-0 PDS interrupted sutures and an easyflow drainage is placed near the duodenotomy (Figure 2D).

$P P D$ : The entrance to the peritoneal cavity and the operative setting is achieved in the same manner as described above. The Treitz ligament is divided to free the fourth portion of the duodenum, and the proximal jejunum is transected with a linear GIA-stapler (Figure 3A). Then the fourth and the third portions of the duodenum are skeletonized and detached from the uncinate process and the head of the pancreas heading up to the level of the papilla (Figure 3B). The branches of the pancreatoduodenal vessels are ligated using a Ligasure ${ }^{\mathrm{TM}}$ Small Jaw Instrument (Covidien, CO, USA) and Prolene 5-0 sutures (Figure 3C). The location of the major papilla is again identified by palpation as described above. The first portion of the duodenum is transected $1.5-2 \mathrm{~cm}$ below the pylorus for preservation of the pyloric function (when this is feasible) and the first two portions of the duodenum are detached from the pancreatic head in the same fashion as the distal duodenum, along with regional lymph nodes. If the duct of Santorini is identified, it is ligated with 5-0 PDS sutures to reduce the risk of a POPF (Figure 3D). At the final step of the resection, the mucosal layer of the major papilla is stripped off by following the Fogarty catheter or the tip of the percutaneous transheptic biliary drainage in the distal CBD. A Billroth II method is preferred in our Department for the reconstruction of the tract.

The transected jejunal limb is brought in a retrocolic fashion to the right of the middle colic vessels to construct an end-to-side papillojejunostomy. The stapler line of the jejunal limb is reinforced with 4-0 PDS interrupted sutures (Figure 3E). A small orifice $(\max 5 \mathrm{~mm})$ at the anti-mesenteric site of the jejunal limb is created. The mucosa of the jejunal orifice is slightly inverted with four interrupted 5-0 PDS sutures, placed in a crosswise fashion, in order to create a mucosa-to-mucosa anastomosis. The edge of a matching pig-tail catheter $(6 \mathrm{Fr})$ is inserted in the main pancreatic duct and in the CBD (in the absence of a percutaneous transheptic biliary drainage catheter) and secured with a 6-0 PDS suture (Figure 3F). If the diameter of the common ostium of the CBD and the main pancreatic duct is too small, an $8 \mathrm{~mm}$ sphincteropapillotomy is performed on the opposite wall of the lumen of the pancreatic duct. For the construction of the singlelayer papillojejunostomy, we use 10-12 5-0 or 6-0 PDS interrupted sutures. All knots of the posterior and the anterior wall remain outside of the anastomosis. Finally, the pylorus is anastomosed to the jejunum, $40-50 \mathrm{~cm}$ distally to the papillojejunostomy in an antecolic fashion. Two drains are placed below and above the papillojejunostomy. During PPD, we routinely perform simultaneous cholecystectomy, since patients after duodenectomy are at risk of developing gallstones due to the lack of postprandial cholecystokinin release in the duodenum (47).

Partial duodenectomy: After an extended right subcostal or midline incision, the peritoneal cavity is carefully explored to exclude systematic spread. To identify the ampulla, the second portion of the duodenum is palpated in a bimanual fashion or a Fogarty catheter is placed from the cystic duct to the CBD. For lesions located at the first duodenal portion, a subtotal gastrectomy with an end-to-side gastrojejunostomy are performed (Billroth II). The first duodenal portion is mobilized from the head of pancreas and the duodenum is transected with GIA-stapler (Covidien) distally to the tumor after safe recognition of the ampulla. A subtotal gastrectomy with a transmesocolic two-layer gastro-enteroanastomosis (Billroth II) is performed (PDS 4-0, Vicryl 4-0, running suture), which is anchored at the mesocolon in order to remain in the lower abdomen.

For lesions located at the fourth duodenal portion, after identifying the ampulla, the fourth duodenal portion is mobilized. The Treitz ligament is then resected and duodenum mobilized from uncinate process. The branches of the pancreatoduodenal vessels are ligated using a Ligasure ${ }^{\mathrm{TM}}$ Small Jaw Instrument and Prolene 5-0 sutures. Finally, a duodenectomy with end-to-end or end-to-side duodenojejunal two-layer anastomosis is performed (PDS 4-0 and Vicryl 40 interrupted sutures).

\section{Results}

In the period from 1996 to 2015, 10 patients underwent PPD and 14 patients underwent TDA for benign, premalignant or early cancerous lesions. The median age of our series was 63 years (range $=38-81$ years). Fifteen of the patients were men. The mean follow-up was 25.8 months (range $=6-54$ months). No patient was lost during the follow-up period.

Twelve of the patients had anemia/upper gastrointestinal bleeding as the presenting symptom, four had pancreatitis, three had vague abdominal pain, one presented with acute abdominal pain, while the rest were incidentally diagnosed after an imaging study performed for another reason. Eighteen patients had preoperative diagnosis of duodenal adenomatosis due to FAP, three patients had preoperative diagnosis of duodenal adenocarcinoma, one had a bleeding polyp and two had localized inflammation. The average operative time was $145 \mathrm{~min}$ (range $=127-168 \mathrm{~min}$ ) in the TDA group and $183 \mathrm{~min}$ (range=173-200 $\mathrm{min}$ ) in the PPD group $(p<0.05)$. The estimated blood loss in the TDA group was $85 \mathrm{ml}$, whereas in the PPD group it was $125 \mathrm{ml}$ $(p<0.05)$. The total average length of stay was 15.1 days (range $=8-25$ days).

Postoperative histological diagnosis confirmed 14 cases of adenoma with various grades of dysplasia (one moderate, eight low and five high), six cases of adenocarcinoma, one case of plexiform fibromyxoma (67), two cases of inflammatory stenosis and one case of gastrointestinal stromal tumor. All patients had intraoperative frozen section 
Table I. Summary of the findings in patients of the present study.

\begin{tabular}{|c|c|c|c|c|c|c|c|c|}
\hline Patient & $\begin{array}{l}\text { Age } \\
\text { (years) }\end{array}$ & Gender & $\begin{array}{l}\text { Indication } \\
\text { for PPD }\end{array}$ & $\begin{array}{l}\text { Type of } \\
\text { operation }\end{array}$ & $\begin{array}{l}\text { Postoperative } \\
\text { diagnosis }\end{array}$ & $\begin{array}{l}\text { Early postoperative } \\
\text { complications }\end{array}$ & $\begin{array}{l}\text { LOS } \\
\text { (days) }\end{array}$ & $\begin{array}{l}\text { Follow-up } \\
\text { (months) }\end{array}$ \\
\hline 1 & 48 & M & Villous adenoma & TDA & Adenoma with HG dysplasia & Pleural effusion & 9 & 54 \\
\hline 2 & 54 & M & Villous adenoma & TDA & Adenoma with HG dysplasia & None & 8 & 54 \\
\hline 3 & 62 & $\mathrm{~F}$ & Ampullary cancer & TDA & Adenocarcinoma (pT1) & Wound infection & 9 & 30 \\
\hline 4 & 67 & M & Villous adenoma & TDA & Adenoma with HG dysplasia & None & 9 & 30 \\
\hline 5 & 58 & M & Villous adenoma & TDA & Unspecified Inflammation & None & 10 & 24 \\
\hline 6 & 70 & $\mathrm{~F}$ & Ampullary cancer & TDA & Adenocarcinoma (pT1) & Atelectasia \& pneumonia & 11 & 24 \\
\hline 7 & 78 & $\mathrm{~F}$ & Villous adenoma & TDA & Adenoma with LG dysplasia & $\begin{array}{c}\text { Duodenal leakage \& } \\
\text { delayed gastric emptying }\end{array}$ & 16 & 24 \\
\hline 8 & 47 & M & Inflammation & TDA & Unspecified inflammation & $\begin{array}{l}\text { Wound infection, } \\
\text { pleural effusion }\end{array}$ & 12 & 24 \\
\hline 9 & 59 & M & Villous adenoma & TDA & Adenoma with HG dysplasia & None & 11 & 20 \\
\hline 10 & 64 & M & Villous adenoma & TDA & Adenoma with LG dysplasia & Pleural effusion & 10 & 12 \\
\hline 11 & 58 & $\mathrm{~F}$ & Villous adenoma & TDA & Unspecified Inflammation & $\begin{array}{c}\text { Pleural effusion \& } \\
\text { pneumonia }\end{array}$ & 15 & 6 \\
\hline 12 & 68 & $\mathrm{~F}$ & Ampullary cancer & TDA & Adenocarcinoma (pT1) & None & 9 & 25 \\
\hline 13 & 51 & M & Villous adenoma & PD (1st and 2nd portion) & Adenoma with HG dysplasia & None & 13 & 24 \\
\hline 14 & 78 & $\mathrm{~F}$ & Villous adenoma & PD (1st and 2nd portion) & Adenoma with LG dysplasia & None & 12 & 27 \\
\hline 15 & 79 & $\mathrm{~F}$ & Villous adenoma & PD (1st and 2nd portion) & Adenoma with LG dysplasia & None & 11 & 26 \\
\hline 16 & 53 & M & Villous adenoma & TDA & $\begin{array}{c}\text { Adenoma with moderate } \\
\text { dysplasia }\end{array}$ & $\begin{array}{l}\text { Fever, pleural n } \\
\quad \text { effusio }\end{array}$ & 19 & 36 \\
\hline 17 & 47 & M & Inflammation & $\begin{array}{l}\text { PD (2nd portion } \\
\text { of duodenum) }\end{array}$ & Unspecified inflammation & Fever & 13 & 48 \\
\hline 18 & 79 & M & Villous adenoma & PD (1st and 2nd portion) & Adenoma with HG dysplasia & None & 11 & 25 \\
\hline 19 & 73 & $\mathrm{~F}$ & Villous adenoma & PD (1st and 2nd portion) & Adenocarcinoma (pTis) & None & 12 & 36 \\
\hline 20 & 81 & M & Villous adenoma & PPD (total) & Adenocarcinoma (pTis) & Wound infection & 23 & 12 \\
\hline 21 & 70 & M & $\begin{array}{l}\text { Bleeding duodenal } \\
\text { polyp }\end{array}$ & $\begin{array}{l}\text { PD (2nd portion } \\
\text { of duodenum) }\end{array}$ & Plexiform fibromyxoma & $\begin{array}{l}\text { Delayed gastric emptying, } \\
\text { pancreatic fistula }\end{array}$ & 18 & 18 \\
\hline 22 & 80 & M & Villous adenoma & TDA & Adenocarcinoma (pTis) & Fever & 15 & 8 \\
\hline 23 & 65 & $\mathrm{~F}$ & Villous adenoma & PPD (total) & GIST & $\begin{array}{l}\text { Bile leak, delayed } \\
\text { gastric emptying }\end{array}$ & 20 & 7 \\
\hline 24 & 38 & M & Villous adenoma & PD (1st and 2nd portion) & Adenoma with LG dysplasia & Pleural effusion & 25 & 25 \\
\hline
\end{tabular}

M: Male, F: female, TDA: transduodenal ampullectomy, PD: Partial duodenectomy, PPD: pancreas-preserving duodenectomy, LG: low-grade, HG: high-grade, LOS: length of stay, GIST: gastrointestinal stromal tumor.

with negative results for malignancy. All patients diagnosed with invasive adenocarcinoma underwent PD as a finite treatment (except for the three cases where poor performance status prohibited PD as noted above).

Early postoperative complications were noted in 13 cases $(54.17 \%)$. Three cases were classified as Clavien-Dindo IIIa, two as II and eight cases as I. The majority of complications included postoperative pleural effusion (five cases), fever resolving with antibiotics (three cases), wound infection (three cases) and bile leak (one case), POPF (one case) and DGE (three cases). One patient had a late complication, anastomotic stenosis treated by endoscopic means. Two patients needed a 2-day stay in the Intensive Care Unit due to comorbidities. There were no postoperative deaths (90-day). During the follow-up, there were no recurrences of duodenal neoplasia. Table I summarizes the findings of this study.

\section{Discussion}

The standard surgical approach for duodenal lesions is PD to achieve clear surgical margins and an adequate lymph node harvest (68). For unique lesions of the duodenum, several alternatives to PD have been described, including ampullectomy (TDA), partial duodenectomy, and PPD. In this report we describe a 20-year experience with these alternatives to $\mathrm{PD}$ in patients with benign and very earlystage duodenal malignancy.

PPD has several theoretical advantages over PD, including preservation of exocrine/endocrine function and avoiding pancreaticojejunostomy, thereby minimizing anastomotic leak and pancreatic fistula rates $(69,70)$. In addition, the gastrointestinal tract can be maintained in continuity to facilitate endoscopic surveillance $(24,43)$. Recent studies comparing PD with PPD in patients with premalignant/low-grade malignant 
Table II. Summary of current literature on pancreas-preserving duodenectomy (PPD) for duodenal lesions.

\begin{tabular}{|c|c|c|c|c|c|c|c|}
\hline Author & Year & $\begin{array}{l}\text { Study } \\
\text { design }\end{array}$ & $\begin{array}{l}\text { Indication } \\
\text { for PPD }\end{array}$ & $\begin{array}{c}\text { Number of } \\
\text { patients }\end{array}$ & $\begin{array}{l}\text { f Perioperative } \\
\text { mortality, } \mathrm{n}(\%)\end{array}$ & $\begin{array}{c}\text { Perioperative } \\
\text { morbidity, n (\%) }\end{array}$ & $\begin{array}{l}\text { Median follow-up till } \\
\text { endpoint (months) }\end{array}$ \\
\hline Chung et al. (15) & 1995 & $\mathrm{CS}$ & FAP & 5 & $0(0)$ & $3(60)$ & 36 \\
\hline Kawano et al. (28) & 1995 & $\mathrm{CR}$ & Duodenal leiomyosarcoma & 1 & $0(0)$ & $0(0)$ & 9 \\
\hline Maher et al. (36) & 1996 & RS & Adenocarcinomas, Crohn & 24 & $1(4.1)$ & $6(25)$ & 24.2 (mean) \\
\hline Tsiotos and Sarr (54) & 1998 & CS & $\begin{array}{l}\text { FAP and broad-based } \\
\text { villous adenomas }\end{array}$ & 4 & $0(0)$ & $1(25)$ & 6.5 (mean) \\
\hline Sohn et al. (49) & 1998 & $\mathrm{CR}$ & Adenocarcinoma & 13 & $0(0)$ & $4(30)$ & $\mathrm{N} / \mathrm{R}$ \\
\hline Alarcon et al. (17) & 1999 & $\mathrm{CS}$ & FAP & 3 & $0(0)$ & $0(0)$ & 45.7 (mean) \\
\hline Nagai et al. (40) & 1999 & $\mathrm{CS}$ & $\begin{array}{l}\text { Trauma, MALT lymphoma, } \\
\text { corrosive necrosis, bleeding, } \\
\text { leiomyosarcoma and } \\
\text { congenital stenosis. }\end{array}$ & 3 & $2(33.3)$ & $1(16.7)$ & 7 \\
\hline Suzuki and Yasui (52) & 1999 & $\mathrm{CR}$ & GIST & 1 & $0(0)$ & $1(100)$ & $\mathrm{N} / \mathrm{R}$ \\
\hline Farnell et al. (25) & 2000 & $\mathrm{CS}$ & $\begin{array}{l}\text { Duodenal adenomas, } \\
\text { carcinoma in situ and } \\
\text { invasive carcinoma }\end{array}$ & 5 & $0(0)$ & $4(80)$ & 64 (mean) \\
\hline Orda et al. (41) & 2000 & $\mathrm{CR}$ & GIST & 1 & $0(0)$ & $0(0)$ & 156 \\
\hline Konsten et al. (32) & 2002 & $\mathrm{CS}$ & FAP and dysplastic & 4 & $0(0)$ & $2(50)$ & 18 \\
\hline Ammori (19) & 2002 & $\mathrm{CR}$ & Benign stricture & 1 & $0(0)$ & $1(100)$ & 3 \\
\hline Kalady et al. (27) & 2002 & $\mathrm{CS}$ & FAP & 3 & $0(0)$ & $2(66.7)$ & 26 (mean) \\
\hline Lundell et al. (34) & 2002 & CS & FAP, adenoma, lipoma & 4 & $0(0)$ & $2(50)$ & 6 \\
\hline Sarmiento et al. (47) & 2002 & $\mathrm{CS}$ & FAP and adenoma & 8 & $0(0)$ & $5(62.5)$ & 21 \\
\hline Takagi et al. (53) & 2003 & $\mathrm{CR}$ & Duodenal carcinoid & 1 & $0(0)$ & $0(0)$ & 1 \\
\hline $\begin{array}{l}\text { de Vos tot Nederveen } \\
\text { Cappel } \text { et al. }(23)\end{array}$ & 2003 & $\mathrm{CS}$ & $\begin{array}{l}\text { Duodenal carcinoma and } \\
\text { adenomatosis in patients with FAP }\end{array}$ & 6 & $0(0)$ & $4(66.7)$ & 11 \\
\hline Eisenberger et al. (24) & 2004 & $\mathrm{CR}$ & Gardner syndrome and adenoma & 2 & $0(0)$ & $1(50)$ & 24 \\
\hline Imamura et al. (26) & 2005 & $\mathrm{CS}$ & FAP, amyloidosis, gastrinoma & 3 & $0(0)$ & $0(0)$ & 8 \\
\hline Kimura et al. (29) & 2005 & $\mathrm{CR}$ & Retroperitoneal liposarcoma & 1 & $0(0)$ & $0(0)$ & 2 \\
\hline Koninger et al. (30) & 2005 & CS & Duodenal adenomas with dysplasia & 7 & $0(0)$ & $3(42.9)$ & 20 \\
\hline Mackey et al. (35) & 2005 & $\mathrm{CS}$ & FAP & 21 & $0(0)$ & $8(38.1)$ & 79 \\
\hline Spalding et al. (50) & 2007 & $\mathrm{CS}$ & $\begin{array}{l}\text { Early-stage adenocarcinomas } \\
\text { and GIST }\end{array}$ & 14 & $1(7.1)$ & $3(21.4)$ & 47 \\
\hline Koshariya et al. (33) & 2007 & $\mathrm{CS}$ & Duodenal adenomas & 3 & $0(0)$ & $1(33)$ & 9 \\
\hline Konishi et al. (31) & 2007 & $\mathrm{CS}$ & $\begin{array}{l}\text { Adenoma, cancer, carcinoid } \\
\text { and non-epithelial tumor }\end{array}$ & 16 & $1(6.25)$ & $2(12.5)$ & 65 (mean) \\
\hline De Castro et al. (22) & 2008 & $\mathrm{CS}$ & FAP & 26 & $1(4)$ & $16(62)$ & 52 (mean) \\
\hline Al-Sarireh et al. (18) & 2008 & CS & Large solitary and multiple polyps & 12 & $0(0)$ & $6(50)$ & 20 \\
\hline Muller et al. (38) & 2008 & $\mathrm{CS}$ & FAP, adenomas, NET & 23 & $1(4)$ & $7(30)$ & 23 \\
\hline Wig et al. (56) & 2009 & $\mathrm{CR}$ & Trauma & 2 & $0(0)$ & $1(50)$ & 22 \\
\hline Paluszkiewicz et al. (42) & 2009 & $\mathrm{CR}$ & Trauma, bleeding & 2 & $1(50)$ & $1(50)$ & 1 \\
\hline $\begin{array}{l}\text { Penninga and } \\
\text { Svendsen (43) }\end{array}$ & 2011 & $\mathrm{RS}$ & $\begin{array}{l}\text { Solitary and multiple } \\
\text { adenomas, GIST }\end{array}$ & 13 & $0(0)$ & $6(46)$ & 56 (mean) \\
\hline Muroni et al. (39) & 2012 & $\mathrm{CR}$ & GIST & 1 & $0(0)$ & $0(0)$ & 6 \\
\hline Ravoire et al. (46) & 2012 & $\mathrm{CR}$ & GIST & 1 & $0(0)$ & $1(100)$ & 8 \\
\hline Masrur et al. (37) & 2012 & $\mathrm{CR}$ & Angiodysplasia & 1 & $0(0)$ & $0(0)$ & 2 \\
\hline Atema et al. (20) & 2012 & $\mathrm{CS}$ & Gastrinoma & 2 & $0(0)$ & $1(50)$ & 18 (mean) \\
\hline Cavaniglia et al. & 2012 & $\mathrm{CR}$ & GIST & 1 & $0(0)$ & $0(0)$ & $\mathrm{N} / \mathrm{R}$ \\
\hline Stauffer et al. (51) & 2013 & $\mathrm{CS}$ & $\begin{array}{c}\text { Adenomas and early-stage } \\
\text { carcinomas }\end{array}$ & 10 & $0(0)$ & $2(20)$ & 11.3 (mean) \\
\hline Waisberg et al. (55) & 2013 & $\mathrm{CR}$ & Carcinoid & 1 & $0(0)$ & $0(0)$ & 39.6 (mean) \\
\hline Rangelova et al. (45) & 2015 & $\mathrm{RS}$ & $\begin{array}{l}\text { Premalignant and low-grade } \\
\text { malignant duodenal lesions }\end{array}$ & 20 & $0(0)$ & $11(55)$ & 24 \\
\hline Shimizu et al. (48) & 2015 & $\mathrm{CR}$ & Duodenal adenoma & 1 & $0(0)$ & $0(0)$ & $\mathrm{N} / \mathrm{R}$ \\
\hline Qadan et al. (44) & 2015 & $\mathrm{CR}$ & Duodenal adenomatous polyp & 1 & $0(0)$ & $100(0)$ & $\mathrm{N} / \mathrm{R}$ \\
\hline Abe et al. (16) & 2016 & $\mathrm{CR}$ & Tubular adenoma & 1 & $0(0)$ & $0(0)$ & 6 \\
\hline Total & 1995-2016 & - & More than $60 \%$ suffered from FAP & 274 & $8(0.73)$ & $104(38)$ & - \\
\hline Current study & 2016 & RS & $\begin{array}{l}\text { Benign lesions, low-grade mali- } \\
\text { gnancies or early-stage carcinomas }\end{array}$ & 10 & $0(0)$ & $4(40)$ & 24.8 (mean) \\
\hline
\end{tabular}

CS: Case series, CR: case report, RS: retrospective study, FAP: familial adenomatous polyposis, GIST: gastrointestinal stromal tumor, NET: neuroendocrine tumor, MALT: mucosa-associated lymphoid tissue. 
Papalampros et al: Non-Whipple Operations in Early Cancerous Duodenal Lesions

Table III. Summary of current literature on transduodenal ampullectomy (TDA) for duodenal lesions.

\begin{tabular}{|c|c|c|c|c|c|c|c|}
\hline Author & Year & $\begin{array}{l}\text { Indication } \\
\text { for TDA }\end{array}$ & $\begin{array}{c}\text { No of } \\
\text { patients }\end{array}$ & $\begin{array}{l}\text { Morbidity, } \\
\text { n (\%) }\end{array}$ & $\begin{array}{l}\text { Mortality, } \\
\mathrm{n}(\%)\end{array}$ & $\begin{array}{l}\text { Median follow-up } \\
\text { (months) }\end{array}$ & $\begin{array}{l}\text { Recurrence } \\
(\%)\end{array}$ \\
\hline Gao et al. (83) & 2016 & Early ampullary cancer & 22 & $3(13.6)$ & $0(0)$ & $75(38-143)$ & 31.8 \\
\hline Schneider et al. (76) & 2016 & Adenomas and inflammatory stenosis & 83 & $20(24)$ & $1(1.2)$ & 54 (mean) & 4.5 \\
\hline Lee et al. (82) & 2016 & Early ampullary cancer & 18 & $6(33)$ & $1(5.6)$ & $50(6-148)$ & 33 \\
\hline Song et al. (78) & 2015 & Early ampullary cancer & 26 & $11(42.6)$ & $0(0)$ & $\mathrm{N} / \mathrm{R}$ & 38.5 \\
\hline Lai et al. (77) & 2015 & Ampullary tumors & 15 & $2(13.3)$ & $2(13.3)$ & $\mathrm{N} / \mathrm{R}$ & 13.3 \\
\hline Onkendi et al. (81) & 2014 & Adenomas & 9 & $5(58)$ & $0(0)$ & 52.8 (mean) & 33.3 \\
\hline Mathur et al. (11) & 2014 & Adenomas & 32 & N/A & N/A & 28 & 13 \\
\hline Zhong et al. (12) & 2013 & Invasive ampullary cancer & 17 & $\mathrm{~N} / \mathrm{R}$ & $0(0)$ & 35.6 (mean) & 63 \\
\hline Ceppa et al. (10) & 2013 & Benign ampullary lesions & 41 & $17(42)$ & $0(0)$ & $\mathrm{N} / \mathrm{R}$ & 36.5 \\
\hline Kim et al. (80) & 2011 & Ampullary tumors & 21 & $9(42.8)$ & $0(0)$ & $18(1-72)$ & 4.8 \\
\hline Marina (79) & 2004 & $\begin{array}{l}\text { Ampullary villous adenomas } \\
\text { and adenocarcinomas }\end{array}$ & 8 & $2(25)$ & $0(0)$ & $28.5(6-72)$ & $\mathrm{N} / \mathrm{R}$ \\
\hline Current study & 2016 & $\begin{array}{c}\text { Benign lesions, low-grade malignancies } \\
\text { or early stage carcinomas }\end{array}$ & 14 & $8(57.1)$ & $0(0)$ & 26.5 (mean) & 0 \\
\hline
\end{tabular}

N/R: Not reported, N/A: not available.

lesions of the duodenum demonstrated that PPD was noninferior compared to PD in terms of morbidity, with superiority in terms of POPF, Intensive Care Unit stay, reoperation, mortality rates, blood loss, operative time and cost $(45,71)$.

After reviewing PubMed, we found 274 cases of PPD (total or partial) (Table II). More than $60 \%$ of the cases were patients with FAP and FAP-related duodenal adenomatosis. PPD is ideally suited for patients with FAP since it is known that duodenal cancer is 100 - to 300 -fold more common in patients with FAP compared to the general population (72, 73). PPD is a favorable alternative to PD in this group of patients, for which mortality as high as $6.7 \%$ (74) has been reported. Other indications described for PPD are large benign duodenal villous tumors of the duodenum, gastrointestinal stromal tumors, duodenal carcinoids, gastrinoma, fibromyxoma, and rarely for duodenal trauma $(42,56)$. Finally, there are cases of PPD performed in patients with invasive duodenal cancer, in which there was a high rate of death due to distant metastases, while the rate of locoregional recurrence was low (31).

Our review of the literature demonstrated a very low mortality rate of PPD (less than 1\%) with a relatively high perioperative morbidity rate. In total, 104 out of 274 patients suffered from some early postoperative complication, accounting for a total morbidity rate of $38 \%$. In contrast with our study, anastomotic leakage was the most frequent early postoperative surgical complication (around 55\%) with DGE and postoperative hemorrhage being less common. The majority of PPDs are performed with an open approach, but there are recent reports of minimally-invasive PPDs (robotically or laparoscopically assisted) with promising results in term of technical pitfalls associated with the meticulous dissection necessary when separating the duodenum from the pancreas $(19,37,51,75)$.

TDA is a less invasive procedure compared to PD, mainly indicated for benign lesions such as adenomas and inflammation not treatable by endoscopic means (10-14, 71, 76-83). However, recent data support a potential role of TDA in selected patients with early ampullary cancer (Tis and T1) and it is likely to provide similar clinical outcomes to PD, such as 5-year survival rate and recurrence rate, accompanied by lower surgical morbidity and mortality, estimated blood loss, intraoperative transfusion and operative time (10-14, 71, 76-83).

One issue of concern is the recurrence rate after TDA, varying from $0 \%$, as in our series, to $40 \%$ in the literature (10-14, 71, 76-83) (Table III). Patients with Tis disease seem to have superior results compared to patients with $\mathrm{T} 1$ disease since the latter often have lymph node metastases $(12,82)$. Thus TDA is probably not appropriate for the treatment of T1 ampullary cancer $(12,82)$, unless the patient has a poor performance status and PD is prohibited.

\section{Conclusion}

We presented a series of 24 patients that underwent nonWhipple operations (PPD and TDA) for benign, premalignant or early cancerous duodenal lesions, with low mortality and morbidity rates. PDD is most commonly used in patients with severe duodenal polyposis as a method of removing the entire duodenum, leaving the pancreas in place and creating a reconstruction that allows follow-up endoscopy for surveillance. TDA is ideal for patients with benign duodenal lesions that are too large to be resected endoscopically. 


\section{Supportive Foundations}

None.

\section{Institutional Review Board statement}

This study was reviewed and approved by the Ethics Committee of Laikon General Hospital and Nicosia General Hospital.

\section{Conflicts of Interest}

All Authors declare that they have no competing interests.

\section{Informed Consent Statement}

Patients were not required to give informed consent to the study.

\section{References}

1 Panzeri F, Crippa S, Castelli P, Aleotti F, Pucci A, Partelli S, Zamboni $G$ and Falconi $M$ : Management of ampullary neoplasms: A tailored approach between endoscopy and surgery. World J Gastroenterol 21(26): 7970-7987, 2015.

2 Goldner B and Stabile BE: Duodenal adenocarcinoma: Why the extreme rarity of duodenal bulb primary tumors? Am Surg 80(10): 956-959, 2014.

3 Shapiro AL and Robillard GL: Morphology and variations of the duodenal vasculature; relationship to the problems of leakage from a postgastrectomy duodenal stump, bleeding peptic ulcer and injury to the common duct. Arch Surg 52: 571-602, 1946.

4 Androulakis J, Colborn GL, Skandalakis PN, Skandalakis LJ and Skandalakis JE: Embryologic and anatomic basis of duodenal surgery. Surg Clin North Am 80(1): 171-199, 2000.

5 Troupis TG, Michalinos A, Vlastos D, Protogerou V, Goutas N, Spiliopoulou C and Skandalakis P: Combined variations of superior mesenteric artery branches. Am Surg 80(4): E103-104, 2014.

6 Abe N, Suzuki Y, Masaki T, Mori T and Sugiyama M: Surgical management of superficial non-ampullary duodenal tumors. Dig Endosc 26(Suppl 2): 57-63, 2014.

7 Huttner FJ, Fitzmaurice C, Schwarzer G, Seiler CM, Antes G, Buchler MW and Diener MK: Pylorus-preserving pancreaticoduodenectomy (pp whipple) versus pancreaticoduo-denectomy (classic whipple) for surgical treatment of periampullary and pancreatic carcinoma. Cochrane Database Syst Rev 2: CD006053, 2016.

8 Ansorge C, Strommer L, Andren-Sandberg A, Lundell L, Herrington MK and Segersvard R: Structured intraoperative assessment of pancreatic gland characteristics in predicting complications after pancreaticoduodenectomy. Br J Surg 99(8): 1076-1082, 2012.

9 Orfanidis NT, Loren DE, Santos C, Kennedy EP, Siddiqui AA, Lavu H, Yeo CJ and Kowalski TE: Extended follow-up and outcomes of patients undergoing pancreaticoduodenectomy for nonmalignant disease. J Gastrointest Surg 16(1): 80-87; discussion 87-88, 2012.

10 Ceppa EP, Burbridge RA, Rialon KL, Omotosho PA, Emick D, Jowell PS, Branch MS and Pappas TN: Endoscopic versus surgical ampullectomy: An algorithm to treat disease of the ampulla of vater. Ann Surg 257(2): 315-322, 2013.
11 Mathur A, Paul H, Ross S, Luberice K, Hernandez J, Vice M and Rosemurgy AS: Transduodenal ampullectomy for ampullary adenomas: A safe and effective procedure with long-term salutary outcomes. Am Surg 80(2): 185-190, 2014.

12 Kawabata Y, Ishikawa N, Moriyama I and Tajima Y: What is an adequate surgical management for ptis and pt1 early ampullary carcinoma? Hepatogastroenterology 61(129): 12-17, 2014.

13 Demetriades H, Zacharakis E, Kirou I, Pramateftakis MG, Sapidis N, Kanellos I and Betsis D: Local excision as a treatment for tumors of ampulla of vater. World J Surg Oncol 4: 14, 2006.

14 Yoon YS, Kim SW, Park SJ, Lee HS, Jang JY, Choi MG, Kim WH, Lee KU and Park YH: Clinicopathologic analysis of early ampullary cancers with a focus on the feasibility of ampullectomy. Ann Surg 242(1): 92-100, 2005.

15 Chung RS, Church JM and vanStolk R: Pancreas-sparing duodenectomy: Indications, surgical technique, and results. Surgery 117(3): 254-259, 1995.

16 Abe N, Hashimoto Y, Kawaguchi S, Shimoyama H, Kojima Y, Yoshimoto E, Kondo E, Ohki A, Takeuchi H, Nagao G, Suzuki Y, Masaki T, Mori T and Sugiyama M: Successful treatment of large adenoma extending close to the papilla in the duodenum by laparoscopy-assisted pancreas-sparing duodenectomy. Asian J Endosc Surg 9(1): 52-56, 2016.

17 Alarcon FJ, Burke CA, Church JM and van Stolk RU: Familial adenomatous polyposis: Efficacy of endoscopic and surgical treatment for advanced duodenal adenomas. Dis Colon Rectum 42(12): 1533-1536, 1999.

18 Al-Sarireh B, Ghaneh P, Gardner-Thorpe J, Raraty M, Hartley M, Sutton R and Neoptolemos JP: Complications and follow-up after pancreas-preserving total duodenectomy for duodenal polyps. Br J Surg 95(12): 1506-1511, 2008.

19 Ammori BJ: Laparoscopic pancreas-preserving distal duodenectomy for duodenal stricture related to nonsteroidal antiinflammatory drugs (nsaids). Surg Endosc 16(9): 1362-1363, 2002.

20 Atema JJ, Amri R, Busch OR, Rauws EA, Gouma DJ and Nieveen van Dijkum EJ: Surgical treatment of gastrinomas: A single-centre experience. HPB (Oxford) 14(12): 833-838, 2012.

21 Cavaniglia D, Petrucciani N, Lorenzon L, Caterino S and Cavallini M: Partial duodenectomy with end-to-end anastomosis for duodenal gastrointestinal stromal tumor. Am Surg 78(5): E273-275, 2012.

22 de Castro SM, van Eijck CH, Rutten JP, Dejong CH, van Goor $\mathrm{H}$, Busch OR and Gouma DJ: Pancreas-preserving total duodenectomy versus standard pancreatoduodenectomy for patients with familial adenomatous polyposis and polyps in the duodenum. Br J Surg 95(11): 1380-1386, 2008.

23 de Vos tot Nederveen Cappel WH, Jarvinen HJ, Bjork J, Berk T, Griffioen $\mathrm{G}$ and Vasen HF: Worldwide survey among polyposis registries of surgical management of severe duodenal adenomatosis in familial adenomatous polyposis. Br J Surg 90(6): 705-710, 2003.

24 Eisenberger CF, Knoefel WT, Peiper M, Yekebas EF, Hosch SB, Busch C and Izbicki JR: Pancreas-sparing duodenectomy in duodenal pathology: Indications and results. Hepatogastroenterology 51(57): 727-731, 2004.

25 Farnell MB, Sakorafas GH, Sarr MG, Rowland CM, Tsiotos GG, Farley DR and Nagorney DM: Villous tumors of the duodenum: Reappraisal of local vs. Extended resection. J Gastrointest Surg 4(1): 13-21, discussion 22-13, 2000. 
26 Imamura M, Komoto I, Doi R, Onodera H, Kobayashi H and Kawai Y: New pancreas-preserving total duodenectomy technique. World J Surg 29(2): 203-207, 2005.

27 Kalady MF, Clary BM, Tyler DS and Pappas TN: Pancreaspreserving duodenectomy in the management of duodenal familial adenomatous polyposis. J Gastrointest Surg 6(1): 82-87, 2002 .

28 Kawano N, Ryu M, Kinoshita T, Konishi M, Iwasaki M, Furuse $J$, Yoshino $M$ and Hasebe $T$ : Segmental resection of the duodenum for treating leiomyosarcoma associated with von recklinghausen's disease: A case report. Jpn J Clin Oncol 25(3): 109-112, 1995.

29 Kimura Y, Mukaiya M, Honma T, Okuya K, Akizuki E, Kihara C, Furuhata T, Hata F, Katsuramaki T, Tsukamoto T and Hirata $\mathrm{K}$ : Pancreas-sparing duodenectomy for a recurrent retroperitoneal liposarcoma: Report of a case. Surg Today 35(1): 91-93, 2005

30 Koninger J, Friess H, Wagner M, Kadmon M and Buchler MW: Technique of pancreas-preserving duodenectomy. Chirurg 76(3): 273-281, 2005 (in German).

31 Konishi M, Kinoshita T, Nakagohri T, Takahashi S, Gotohda N and Ryu M: Pancreas-sparing duodenectomy for duodenal neoplasms including malignancies. Hepatogastroenterology 54(75): 753-757, 2007.

32 Konsten JL, Kazemier G, Dees J and van Eijck CH: Pancreaspreserving total duodenectomy due to familial adenomatous polyposis in 4 patients. Ned Tijdschr Geneeskd 146(13): 621624, 2002.

33 Koshariya M, Jagad RB, Kawamoto J, Papastratis P, Kefalourous $\mathrm{H}$, Porfiris T, Gevrielidis P, Tzouma C and Lygidakis NJ: Pancreas-preserving total duodenectomy without pancreatoenteric anastomosis. Hepatogastroenterology 54(79): 2123-2128, 2007.

34 Lundell L, Hyltander A and Liedman B: Pancreas-sparing duodenectomy: Technique and indications. Eur J Surg 168(2): 74-77, 2002.

35 Mackey R, Walsh RM, Chung R, Brown N, Smith A, Church J and Burke C: Pancreas-sparing duodenectomy is effective management for familial adenomatous polyposis. J Gastrointest Surg 9(8): 1088-1093; discussion 1093, 2005.

36 Maher MM, Yeo CJ, Lillemoe KD, Roberts JR and Cameron JL: Pancreas-sparing duodenectomy for infra-ampullary duodenal pathology. Am J Surg 171(1): 62-67, 1996.

37 Masrur M, Gheza F, Raimondi P, D'Ugo S, Calatayud D and Giulianotti PC: Robot-assisted subtotal pancreas-preserving duodenectomy. JSLS 16(4): 654-659, 2012.

38 Muller MW, Dahmen R, Koninger J, Michalski CW, Hinz U, Hartel M, Kadmon M, Kleeff J, Buchler MW and Friess H: Is there an advantage in performing a pancreas-preserving total duodenectomy in duodenal adenomatosis? Am J Surg 195(6): 741-748, 2008.

39 Muroni M, Ravaioli M, Del Gaudio M, Nigri G, D’Angelo F, Uccini S and Ramacciato G: Pancreas-preserving segmental duodenectomy for gastrointestinal stromal tumor of the duodenum and splenectomy for splenic angiosarcoma. Hepatobiliary Pancreat Dis Int 11(3): 325-329, 2012.

40 Nagai H, Hyodo M, Kurihara K, Ohki J, Yasuda T, Kasahara K, Sekiguchi C and Kanazawa K: Pancreas-sparing duodenectomy: Classification, indication and procedures. Hepatogastroenterology 46(27): 1953-1958, 1999.
41 Orda R, Sayfan J and Wasserman I: Surgical treatment of leiomyosarcoma of the distal duodenum. Dig Surg 17(4): 410412, 2000.

42 Paluszkiewicz P, Dudek W, Lowery K and Hart CA: Pancreas sparing duodenectomy as an emergency procedure. World $\mathrm{J}$ Emerg Surg 4: 19, 2009.

43 Penninga L and Svendsen LB: Pancreas-preserving total duodenectomy: A 10-year experience. J Hepatobiliary Pancreat Sci 18(5): 717-723, 2011.

44 Qadan M, Dua M, Worhunsky D, Triadafilopoulos G and Visser B: More with less: Pancreas-preserving total duodenectomy. Dig Dis Sci 60(6): 1565-1568, 2015.

45 Rangelova E, Blomberg J, Ansorge C, Lundell L, Segersvard R and Del Chiaro M: Pancreas-preserving duodenectomy is a safe alternative to high-risk pancreatoduodenectomy for premalignant duodenal lesions. J Gastrointest Surg 19(3): 492-497, 2015.

46 Ravoire A, Poussier M, Facy O, Jouve JL, Funes de la Vega M and Rat P: Multiple duodenal stromal tumors revealing type 1 neurofibromatosis: An indication for pancreas-preserving duodenectomy. Surgery 153(4): 599-600, 2013.

47 Sarmiento JM, Thompson GB, Nagorney DM, Donohue JH and Farnell MB: Pancreas-sparing duodenectomy for duodenal polyposis. Arch Surg 137(5): 557-562; discussion 562-553, 2002.

48 Shimizu K, Hashimoto D, Abe S, Chikamoto A and Baba H: Pancreas-preserving partial duodenectomy of the distal region for large duodenal adenoma: Report of a case. Surg Today 45(3): 390-393, 2015.

49 Sohn TA, Lillemoe KD, Cameron JL, Pitt HA, Kaufman HS, Hruban RH and Yeo CJ: Adenocarcinoma of the duodenum: Factors influencing long-term survival. J Gastrointest Surg 2(1): 79-87, 1998.

50 Spalding DR, Isla AM, Thompson JN and Williamson RC: Pancreas-sparing distal duodenectomy for infrapapillary neoplasms. Ann R Coll Surg Engl 89(2): 130-135, 2007.

51 Stauffer JA, Raimondo M, Woodward TA, Goldberg RF, Bowers SP and Asbun HJ: Laparoscopic partial sleeve duodenectomy (psd) for nonampullary duodenal neoplasms: Avoiding a whipple by separating the duodenum from the pancreatic head. Pancreas 42(3): 461-466, 2013.

52 Suzuki H and Yasui A: Pancreas-sparing duodenectomy for a huge leiomyosarcoma in the third portion of the duodenum. $\mathbf{J}$ Hepatobiliary Pancreat Surg 6(4): 414-417, 1999.

53 Takagi H, Miyairi J, Hata M, Tuboi J, Kamijou T, Nakajima K and Nagai H: Multiple somatostatin- and gastrin-containing carcinoids of the duodenum: Report of a case treated by pancreas-sparing duodenectomy. Hepatogastroenterology 50(51): 711-713, 2003.

54 Tsiotos GG and Sarr MG: Pancreas-preserving total duodenectomy. Dig Surg 15(5): 398-403, 1998.

55 Waisberg J, Joppert-Netto G, Vasconcellos C, Sartini GH, Miranda LS and Franco MI: Carcinoid tumor of the duodenum: A rare tumor at an unusual site. Case series from a single institution. Arq Gastroenterol 50(1): 3-9, 2013.

56 Wig JD, Kudari A, Yadav TD, Doley RP, Bharathy KG and Kalra N: Pancreas preserving total duodenectomy for complex duodenal injury. J Pancreas 10(4): 425-428, 2009.

57 Dindo D, Demartines $\mathrm{N}$ and Clavien PA: Classification of surgical complications: A new proposal with evaluation in a cohort of 6336 patients and results of a survey. Ann Surg 240(2): 205-213, 2004 
58 Wente MN, Veit JA, Bassi C, Dervenis C, Fingerhut A, Gouma DJ, Izbicki JR, Neoptolemos JP, Padbury RT, Sarr MG, Yeo CJ and Buchler MW: Postpancreatectomy hemorrhage (PPH): An international study group of pancreatic surgery (ISGPS) definition. Surgery 142(1): 20-25, 2007.

59 Bassi C, Dervenis C, Butturini G, Fingerhut A, Yeo C, Izbicki J, Neoptolemos J, Sarr M, Traverso W, Buchler M and International Study Group on Pancreatic Fistula D: Postoperative pancreatic fistula: An international study group (isgpf) definition. Surgery 138(1): 8-13, 2005.

60 Wente MN, Bassi C, Dervenis C, Fingerhut A, Gouma DJ, Izbicki JR, Neoptolemos JP, Padbury RT, Sarr MG, Traverso LW, Yeo CJ and Buchler MW: Delayed gastric emptying (DGE) after pancreatic surgery: A suggested definition by the international study group of pancreatic surgery (isgps). Surgery 142(5): 761-768, 2007

61 Azih LC, Broussard BL, Phadnis MA, Heslin MJ, Eloubeidi MA, Varadarajulu S and Arnoletti JP: Endoscopic ultrasound evaluation in the surgical treatment of duodenal and periampullary adenomas. World J Gastroenterol 19(4): 511-515, 2013.

62 Ansorge C, Nordin JZ, Lundell L, Strommer L, Rangelova E, Blomberg J, Del Chiaro M and Segersvard R: Diagnostic value of abdominal drainage in individual risk assessment of pancreatic fistula following pancreaticoduodenectomy. Br J Surg 101(2): 100-108, 2014.

63 Papalampros A, Niehaus K, Moris D, Fard-Aghaie M, Stavrou G, Margonis AG, Angelou A and Oldhafer K: A safe and feasible "clock-face" duct-to-mucosa pancreaticojejunostomy with a very low incidence of anastomotic failure: A single center experience of 248 patients. J Visc Surg 153(6): 425-431, 2016.

64 Papalampros A, Moris D, Felekouras E, Niehaus K and Oldhafer $\mathrm{K}$ : Balance between technical novelty and clinical fidelity is the cornerstone in pancreatic surgery. J Am Coll Surg 222(1): 99, 2016.

65 Felekouras E, Petrou A, Neofytou K, Moris D, Dimitrokallis N, Bramis K, Griniatsos J, Pikoulis E and Diamantis T: Early or delayed intervention for bile duct injuries following laparoscopic cholecystectomy? A dilemma looking for an answer. Gastroenterol Res Pract 2015: 104235, 2015.

66 Moris D, Papalampros A, Vailas M, Petrou A, Kontos M and Felekouras E: The hepaticojejunostomy technique with intraanastomotic stent in biliary diseases and its evolution throughout the years: A technical analysis. Gastroenterol Res Pract 2016: 3692096, 2016.

67 Moris D, Spanou E, Sougioultzis S, Dimitrokallis N, Kalisperati P, Delladetsima I and Felekouras E: Duodenal plexiform fibromyxoma as a cause of obscure upper gastrointestinal bleeding: A case report. Medicine 96(1): e5883, 2017.

68 Petrou A, Soonawalla Z, Silva MA, Manzelli A, Moris D, Tabet $\mathrm{PP}$ and Friend P: Prognostic indicators following curative pancreatoduodenectomy for pancreatic carcinoma: A retrospective multivariate analysis of a single centre experience. J BUON 21(4): 874-882, 2016.

69 Cloyd JM, Kastenberg ZJ, Visser BC, Poultsides GA and Norton JA: Postoperative serum amylase predicts pancreatic fistula formation following pancreaticoduodenectomy. J Gastrointest Surg 18(2): 348-353, 2014.
70 Gouma DJ, van Geenen RC, van Gulik TM, de Haan RJ, de Wit LT, Busch OR and Obertop H: Rates of complications and death after pancreaticoduodenectomy: Risk factors and the impact of hospital volume. Ann Surg 232(6): 786-795, 2000.

71 Nakayama Y, Konishi M, Gotohda N, Kato Y, Aizawa H, Kudo M, Okubo S, Takahashi D, Nishida Y, Kitaguchi K and Takahashi S: Comparison of postoperative early and late complications between pancreas-sparing duodenectomy and pancreatoduodenectomy. Surg Today doi:10.1007/s00595-016-1418-1411, 2016.

72 Arvanitis ML, Jagelman DG, Fazio VW, Lavery IC and McGannon E: Mortality in patients with familial adenomatous polyposis. Dis Colon Rectum 33(8): 639-642, 1990.

73 Groves CJ, Saunders BP, Spigelman AD and Phillips RK: Duodenal cancer in patients with familial adenomatous polyposis (FAP): Results of a 10-year prospective study. Gut 50(5): 636641, 2002.

74 Gallagher MC, Shankar A, Groves CJ, Russell RC and Phillips RK: Pylorus-preserving pancreaticoduodenectomy for advanced duodenal disease in familial adenomatous polyposis. Br J Surg 91(9): 1157-1164, 2004.

75 Benetatos N, Ammori MB and Ammori BJ: Laparoscopic pancreas-preserving total duodenectomy for familial adenomatous polyposis. Surg Laparose Endosc Percutan Tech 21(6): e332-335, 2011.

76 Schneider L, Contin P, Fritz S, Strobel O, Buchler MW and Hackert T: Surgical ampullectomy: An underestimated operation in the era of endoscopy. HPB 18(1): 65-71, 2016.

77 Lai JH, Shyr YM and Wang SE: Ampullectomy versus pancreaticoduodenectomy for ampullary tumors. J Chin Med Assoc 78(6): 339-344, 2015.

78 Song J, Liu H, Li Z, Yang C, Sun Y and Wang C: Long-term prognosis of surgical treatment for early ampullary cancers and implications for local ampullectomy. BMC Surg 15: 32, 2015.

79 Fraguela Marina JA: Transduodenal ampullectomy in the treatment of villous adenomas and adenocarcinomas of the Vater's ampulla. Rev Esp Enferm Dig 96(12): 829-834, 2004.

$80 \mathrm{Kim}$ J, Choi SH, Choi DW, Heo JS and Jang KT: Role of transduodenal ampullectomy for tumors of the ampulla of vater. J Korean Surg Soc 81(4): 250-256, 2011.

81 Onkendi EO, Naik ND, Rosedahl JK, Harmsen SW, Gostout CJ, Baron TH Sr., Sarr MG and Que FG: Adenomas of the ampulla of Vater: A comparison of outcomes of operative and endoscopic resections. J Gastrointest Surg 18(9): 1588-1596, 2014.

82 Lee H, Park JY, Kwon W, Heo JS, Choi DW and Choi SH: Transduodenal ampullectomy for the treatment of early-stage ampulla of Vater cancer. World J Surg 40(4): 967-973, 2016.

83 Gao Y, Zhu Y, Huang X, Wang H, Huang X and Yuan Z: Transduodenal ampullectomy provides a less invasive technique to cure early ampullary cancer. BMC Surg 16(1): 36, 2016.

Received January 8, 2017

Revised February 13, 2017 Accepted February 14, 2017 